\title{
Chimeric free fibula lateral supramalleolar flap in selected cases of mandible \& maxilla defects- A pilot study
}

\author{
Ravikiran Naalla*, Rajan Arora*, Kripa Shanker Mishra*, Ajay Kumar Dewan**, Mudit Agarwal**, \\ Saket Srivastava*, Aditya Narayan Choudhary* \\ *Division of Reconstructive Microsurgery, Department of Surgical Oncology, \\ * * Department of Surgical Oncology,
}

Rajiv Gandhi Cancer Institute \& Research Center, New Delhi

DOI: 10.29322/IJSRP.11.09.2021.p11736

http://dx.doi.org/10.29322/IJSRP.11.09.2021.p11736

\begin{abstract}
Background: Reconstruction of complex three-dimensional defects following composite mandibular resections is a challenge. Dual skin paddle fibula flap, double free flap, chimeric scapula flap, iliac flaps have been described for reconstruction of these defects. The combination of supramalleolar flap along with fibula flap in a chimeric fashion was less explored and its feasibility to use when harvested from an ipsilateral leg was never studied. We aimed to assess this feasibility.

Material \& methods: Chimeric free fibula lateral supramalleolar flap (CFSMF) harvest was attempted in 15 patients by the first three authors. The study was conducted between November 2020 and May 2021 (6 months). The study feasibility was analyzed based on defined criteria.

Result: The flap could be harvested successfully in 12 patients. The mean age of the study population was 47.5 years (range: 25-59 years). There were 12 male and 3 female patients. The mean distance of the skin perforator from the lateral malleolus was $6.2 \mathrm{~cm}$ (range $4-8 \mathrm{~cm}$ ). All the chimeric flap components survived except two lateral supramalleolar artery perforator flaps (SMF). There were no other complications. None of the patients had donor site complications. All flaps could be successfully used for the intended purpose.

Conclusion: Utilization of CFSMF in day-to-day practice is feasible with certain modifications. It a good choice for the reconstruction of selected composite mandibular defects. The flap combination has several innovative applications as described, a study with a larger sample size would show wider perspectives on this chimeric flap.
\end{abstract}

Index Terms- Chimeric flap, fibula, supramalleolar flap, head \& neck reconstruction

\section{INTRODUCTION:}

Extirpation of advanced head \& neck malignancies may result in large complex three-dimensional defects. These could be extensive composite defects that need reconstruction of the mucosa, bone, skin. In addition to this, the soft tissue defect needs to be obliterated to prevent seroma, hematoma, and infection. On several occasions, multiple anatomical \& functional subunits of the oral cavity are resected due to the multifocal disease. The latter scenario is a reconstructive challenge since even the composite flap components are relatively immobile to facilitate a three-dimensional insetting. In this era of advanced microsurgery, an emphasis has to be put on aesthetic considerations in addition to functional rehabilitation.

Though double-free flap ${ }^{1-3}$, chimeric scapula flap ${ }^{4}$, and hybrid flap combinations ${ }^{5}$ are promising options for extensive composite mandibular defects, they all have several limitations and may not be feasible or suitable for all patients/ surgeons. A chimeric fibula flap and lateral supramalleolar flap was first described by Sicilia-Castro. ${ }^{6}$ Subsequently, to date, there has been a single case series which was published by Massarelli $\mathrm{O}$ et $^{-7}{ }^{7}$ (to the best of our knowledge). The authors had shown several distinct advantages of this chimeric flap combination. Our study aimed to investigate the feasibility of the application of Chimeric free fibula lateral supramalleolar flap (CFSMF) from the ipsilateral leg in day-to-day practice. The flap combination was never reported when the fibula flap was harvested from the ipsilateral leg. We have conducted a pilot study to assess this feasibility.

\section{MATERIAL \& METHODS:}

CFSMF flap harvest was attempted in 15 patients by the first three authors. The study was conducted at a tertiary referral oncology hospital between November 2020 and May 2021 (6months). A retrospective analysis of these patients was done. The oromandibular 
defects associated with defects in the tongue, cervicofacial skin, and contralateral buccal mucosa were included. Maxillary defects which require multiple skin islands in addition to the fibula flap were also included. The patients with oromandibular defects which can be managed with a conventional fibula flap or a double skin paddle fibula flap were excluded.

The primary objective was to assess feasibility in terms of a) ability to harvest the CFSMF, b) ability to use the CFSMF for the proposed defects, c) flap survival, d) complications associated with flap combination. The secondary objective was to propose the technical details and clinical applications of CFSMF.

The study will be considered feasible if the flap is successfully utilized in the proposed defects without any significant additional complications. The study will be considered feasible with modifications if any improvements could lead to improved outcomes. The study will be considered not feasible if the flap combination is not possible for the desired defects.

\section{Technique:}

As a unit protocol, we use an ipsilateral fibula flap with flexor hallucis longus (FHL) for all mandibular and maxillary defects. We follow a two-team approach, the flap harvest and tumor resection by the onco-surgeon are done simultaneously. The patient was placed in a supine position with knee flexed at ninety degrees. The fibula outline was marked. The lateral supramalleolar flap, also termed as supramalleolar flap (SMF) was designed over the anterolateral aspect of the distal $1 / 3^{\text {rd }}$ of the leg. The blood supply of these flap is based on the distal peroneal artery perforating branch and its vena comitantes (one artery and two venacomitantes). The distal perforating artery arises from the terminal portion peroneal artery after the later gives off all the fibula skin paddle perforators. The distal perforating branch passes in the anterior intermuscular septum by piercing the interosseus membrane. Skin perforator(s) emerge from the distal perforating branch and nourishes the SMF. The perforator was marked with a handheld doppler, 4-8 $\mathrm{cm}$ superior to the tip of the lateral malleolus, anterior to the fibula. An anterior exploratory incision was marked to harvest the osteo-myocutanoeus fibula flap. The procedure was started with the harvest of SMF. The anterior margin of the flap was incised and the flap was elevated from medial to the lateral direction in a suprafascial fashion. The fascia was incised at the lateral margin of the extensor digitorum longus (EDL). The flap was then dissected in a subfascial plane. The peroneal artery perforating branch is identified between EDL and peroneus brevis muscle. It passes along the distal portion of the anterior inter muscular septum (anterior to the fibula). On the other hand, the perforators nourishing the fibula skin paddle traverse through the posterior intermuscular septum (posterior to the fibula). A skin perforator from this perforating branch supplying the SMF has to be identified and included in the flap design (Figure 1).

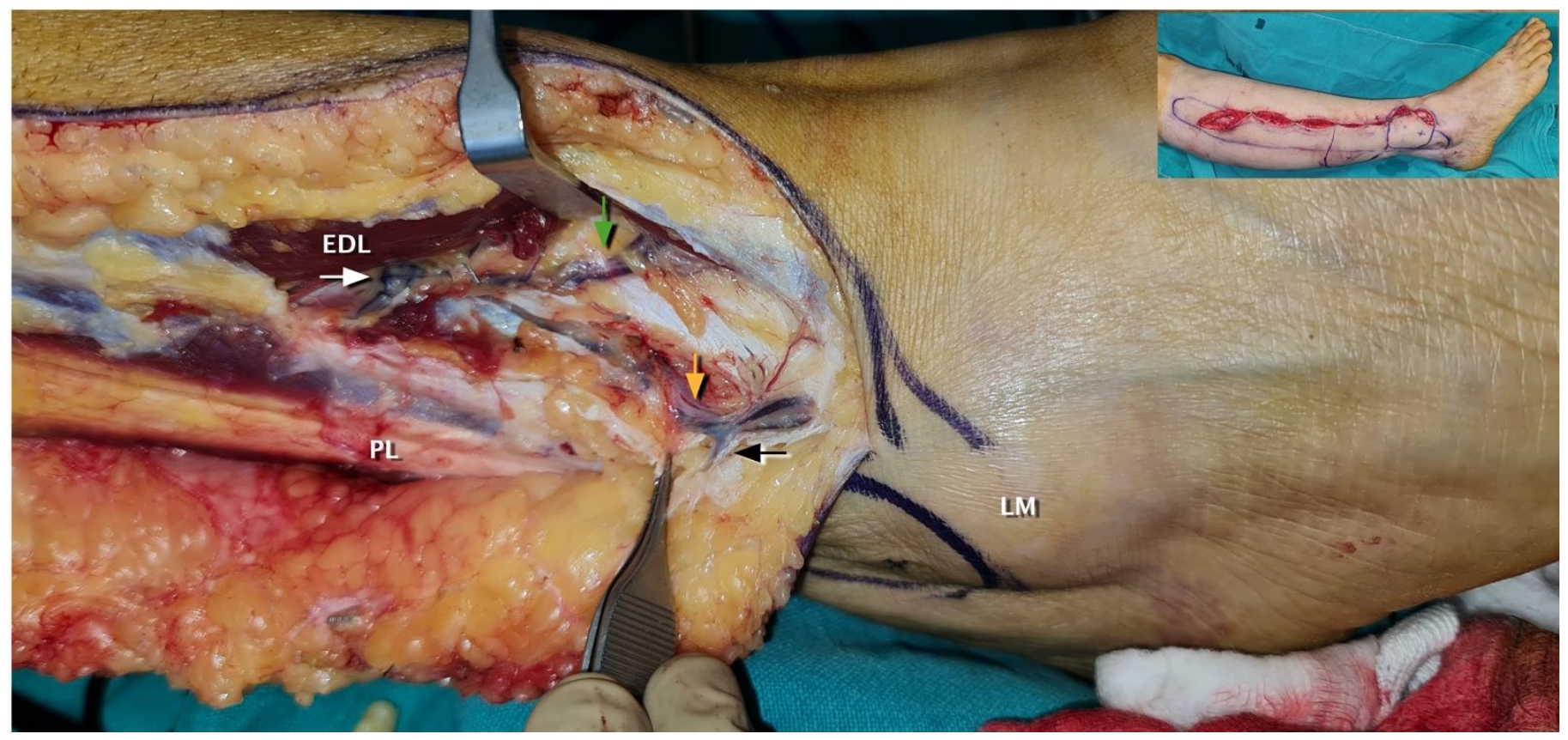

Figure 1: Image showing the anatomy of the perforating branch of peroneal artery and its skin perforator supplying the SMF. The white arrow indicates the location at which the perforating branch pierces the interosseous membrane, the yellow arrow indicates the perforating branch of peroneal artery lying in between the extensor digitorum longus (EDL) and peroneus longus (PL). The green arrow shows the communication of perforating branch and the anterior tibial vessels. The black arrow shows the skin perforator arising from the perforating branch. (LM- lateral malleolus, image in the inset shows the marking of fibula skin paddle and SMF above and below respectively. 
The osteo-myocutaneous fibula flap was harvested by an anterior approach. With the anterior exploratory incision, the skin flap was raised in a suprafascial manner. The skin perforators were identified in the posterior intermuscular septum. The peroneal muscles were dissected off the fibula. The anterior septum was cut and the extensor compartment muscles were dissected off the fibula. Upper and lower osteotomy were made and the interosseous membrane was divided. The tibialis posterior muscle was divided. The FHL was divided at the distal osteotomy site to be included in the flap. In the distal leg, the peroneal artery pierces the interosseous membrane and continues as the perforating branch. In a conventional fibula flap harvest, we ligate the peroneal artery before it pierces the interosseous membrane. In CFSMF, the distal peroneal artery shouldn't be ligated. The peroneal artery and its perforating branch which pierces the interosseous membrane have to be dissected in continuity. This is the most crucial step. The posterior incision of SMF was made and the perforating branch was islanded. The perforating branch was dissected towards the area where it pierces the interosseous membrane. The communicating branch to the anterior tibial vessels should be clipped and divided. The distal end of the perforating branch was clipped and cut; the flap was harvested distal to proximal. Once the dissection is done, the SMF is tunneled under the peroneus longus to reach the posterolateral aspect of the leg. At this stage, the tourniquet was released and we wait for the onco-surgeon to finish the resection. Once the tumor resection was completed and defect analysis was done, the skin paddle dimensions were marked. The lesser saphenous vein and the sural nerve were preserved. A posterior skin paddle incision was then made. The transposed SMF and the osteo-myocutaneous fibula flap were harvested together as two independent mobile components supplied by the same source vessel. The fibula osteotomy and miniplate fixation were done in situ after deflating the tourniquet. The peroneal vessels were divided once the perfusion was good for both flaps. In our experience, SMF always underwent vessel spasm, and papaverine was used to relieve the spasm. Following fibula flap inset and anastomosis, it is always prudent to examine the perforating branch of the peroneal artery under the microscope to secure hemostasis. Donor site closure and a skin graft was applied. The patient was ambulated on postoperative day 5.

\section{RESULTS:}

The flap could be harvested successfully in 12 patients. The flap couldn't be harvested in the rest of the three patients due to the following reasons: accidental clipping of the perforating branch of the peroneal artery, and uncertainty of perforator anatomy. The mean age of the study population was 47.5 years (range: 25-59 years). There were 12 male and 3 female patients. The diagnosis, staging, nature of the defect, and the purpose of SMF were tabulated (Table 1). The mean distance of the skin perforator from the lateral malleolus was $6.2 \mathrm{~cm}$ (range $4-8 \mathrm{~cm}$ ). All the chimeric flap components survived except two SMF flaps (out of $12 \mathrm{SMF}$ flaps, $16.6 \%$ ). One of the SMF flaps was gangrenous on POD-5 due to an arterial compromise. In this particular case, the fibula skin paddle was healthy. So, we assumed that the arterial compromise might be due to an intimal damage due to stretch in the pedicle while harvesting, or persistent arterial spasm. The second SMF flap loss was due to excessive stretch in the pedicle during flap inset. Both of them were managed with a skin graft as the resultant defects after debridement were non-critical. There were no other flap-related complications. None of the patients had donor site complications. The mean follow-up duration was 115.5 days (range: 50-155 days). All flaps could be successfully used for the intended purpose.

\section{Case series:}

\section{Case 1 (Composite mandible central arch \& tongue reconstruction):}

A 34-year-old male was diagnosed with carcinoma of the lower alveolus (cT4aN2M0). He underwent central arch mandibulectomy, wide local excision (WLE) of the floor of mouth \& chin skin, and bilateral neck dissection. He underwent a CFSMF flap from the left leg. The dimension of bone was right body- $4 \mathrm{~cm}$; central segment $-2.5 \mathrm{~cm}$; left body- $3.5 \mathrm{~cm}$. The skin paddle of the fibula flap was $25 \mathrm{x} 7$ $\mathrm{cm}$ was based on 3 perforators. The SMF was $6 \times 5 \mathrm{~cm}$. Following the plating of the fibula bone to the native mandible, the skin paddle of the fibula flap was folded and partially de-epithelized to resurface the floor of the mouth (FOM), lower buccal sulcus (LBS), and the chin skin. The SMF was used to reconstruct the ventral surface of the tongue. The long vascular pedicle and thin SMF facilitated independent soft tissue coverage. The flap artery was anastomosed to the left facial artery and one of the venae comitantes was anastomosed to the common facial vein with a $3.5 \mathrm{~mm}$ venous coupler. By this independent inset, the tethering effect of the fibula skin to the tongue could be prevented. Most of the fibula skin paddle was consumed in the resurfacing of FOM, LBS, and chin skin. Thus, SMF added a $6 \times 5 \mathrm{~cm}$ flap surface area. The patient underwent excision of the dog ear after 2 weeks. The postoperative stay was uneventful and the patient had an acceptable outcome in terms of appearance and intelligibility of speech (Figure 2, 3). 


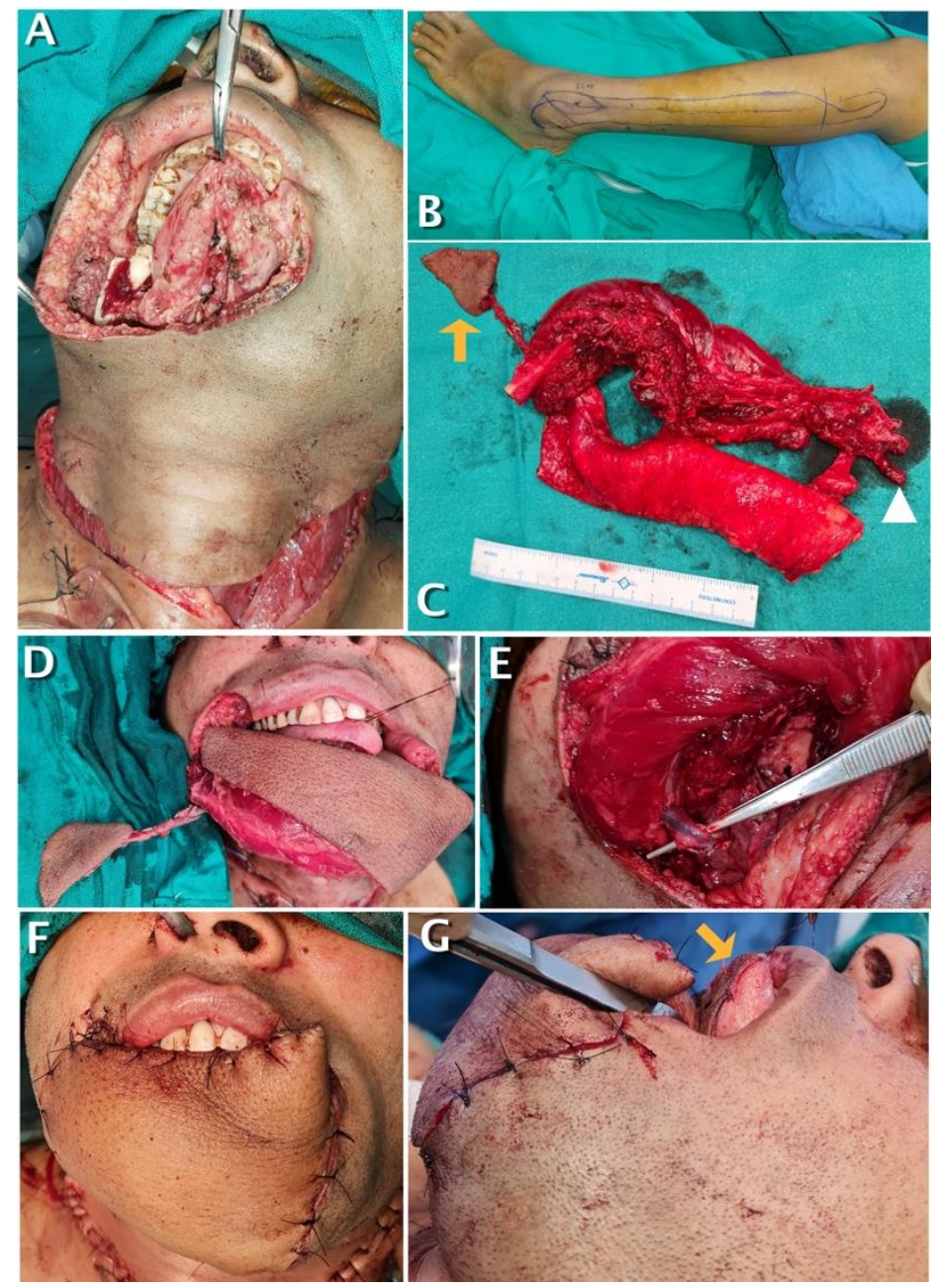

Figure 2: Image showing (A) intraoperative image of extensive composite central arch resection, (B) marking of CFSMF, (C) harvested CFSMF (yellow arrow indicates the supramalleolar flap, white arrowhead indicates the fibula flap), (D) before inset of fibula skin paddle \& supramalleolar flap, (E) SMF was tunneled under the FHL to cover the defect over the ventral aspect of the tongue (the tunneled vascular pedicle of SMF is shown over the forceps), (F, G) inset of folded fibula skin paddle and SMF (yellow arrow). 

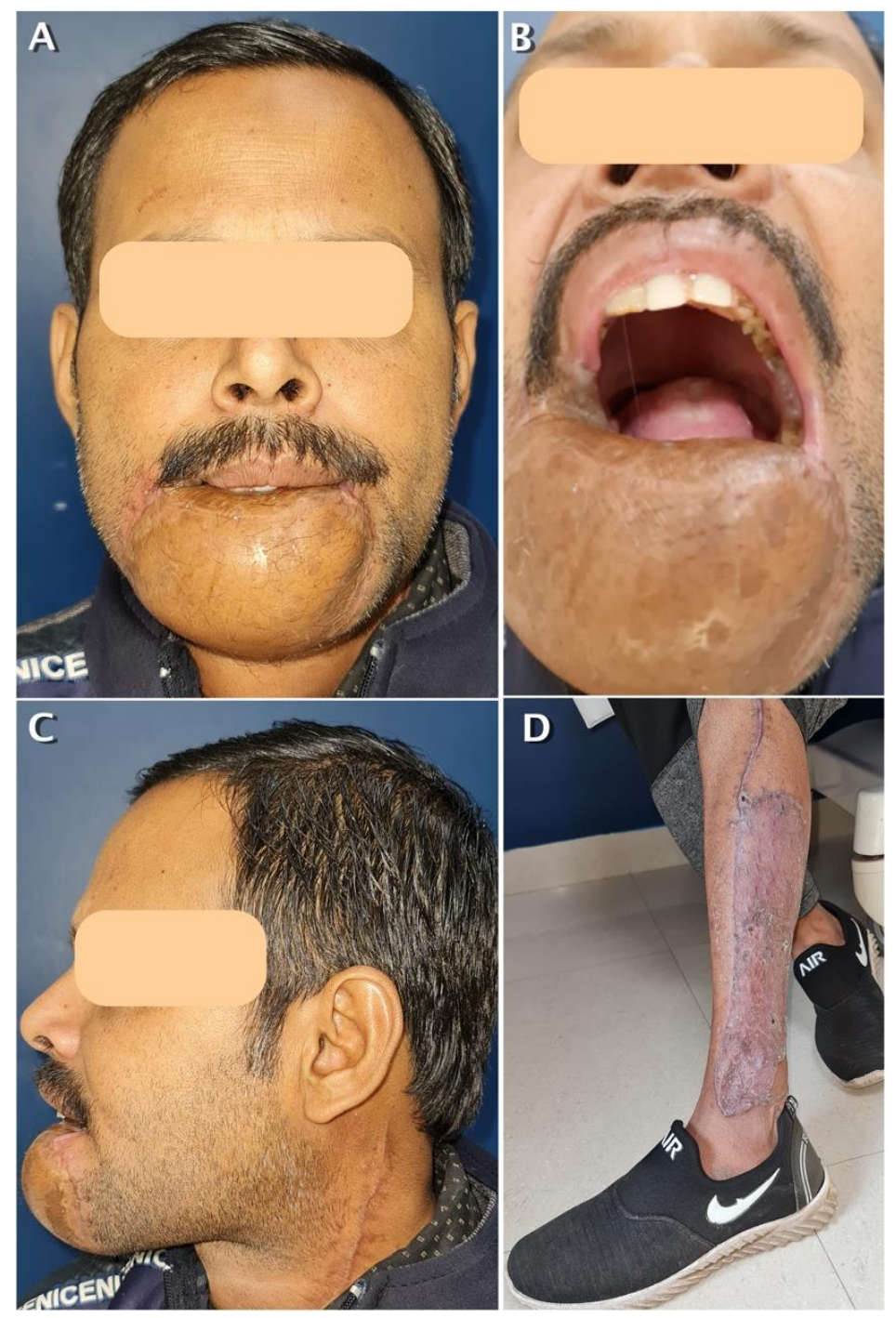

Figure 3: Image showing (A-C) well-settled flap, (D) donor site skin graft. 
Table 1. Patient and flap characteristics of the study population

\begin{tabular}{|c|c|c|c|c|c|c|c|c|c|c|c|}
\hline \multirow[t]{2}{*}{ S.no } & \multirow{2}{*}{$\begin{array}{l}\text { Age } \\
\text { (year } \\
\text { s) }\end{array}$} & \multirow[t]{2}{*}{ Sex } & \multirow[t]{2}{*}{ Diagnosis } & \multirow[t]{2}{*}{ Stage } & \multicolumn{2}{|l|}{ Defect } & \multirow{2}{*}{$\begin{array}{l}\text { Use of Fibula } \\
\text { Skin paddle } \\
(\mathrm{cm})\end{array}$} & \multirow{2}{*}{$\begin{array}{l}\text { Use of SMF } \\
\text { (cm) }\end{array}$} & \multirow{2}{*}{$\begin{array}{l}\text { Recipie } \\
\text { nt } \\
\text { vessels }\end{array}$} & \multirow{2}{*}{$\begin{array}{l}\text { Complicatio } \\
\mathrm{n}\end{array}$} & \multirow[t]{2}{*}{ Remark } \\
\hline & & & & & Bone & Soft tissue & & & & & \\
\hline 1. & 34 & $\mathrm{M}$ & $\begin{array}{l}\text { Carcinoma lower } \\
\text { alveolus (central arch) }\end{array}$ & T4aN2M0 & $\begin{array}{l}\text { B (right)- } 4 \\
\mathrm{~cm} \\
\text { CS- } 2.5 \mathrm{~cm} \\
\text { B (left)- } \\
3.5 \mathrm{~cm}\end{array}$ & $\begin{array}{l}\text { Mucosa, } \\
\text { Chin skin, } \\
\text { Ventral tongue }\end{array}$ & $\begin{array}{l}\text { Mucosal } \\
\text { defect, } \\
\text { Chin skin } \\
(25 \times 7 \mathrm{~cm})\end{array}$ & $\begin{array}{l}\text { Ventral } \\
\text { tongue } \\
(6 \times 5 \mathrm{~cm})\end{array}$ & $\begin{array}{l}\text { Left } \\
\text { FA, } \\
\text { CFV }\end{array}$ & Nil & Nil \\
\hline 2. & 38 & $\mathrm{M}$ & $\begin{array}{l}\text { Carcinoma right buccal } \\
\text { mucosa and submucous } \\
\text { fibrosis left buccal } \\
\text { mucosa }\end{array}$ & T4aN1M0 & $\begin{array}{l}\mathrm{R}-3 \mathrm{~cm} \\
\mathrm{~B}-6.5 \mathrm{~cm}\end{array}$ & $\begin{array}{l}\text { Mucosa, } \\
\text { Contralateral } \\
\text { buccal mucosa }\end{array}$ & $\begin{array}{l}\text { Mucosa } \\
(14 \times 8 \mathrm{~cm})\end{array}$ & $\begin{array}{l}\text { Contralateral } \\
\text { buccal } \\
\text { mucosa } \\
(7 \times 6 \mathrm{~cm})\end{array}$ & $\begin{array}{l}\text { Right } \\
\text { FA, } \\
\text { IJV }\end{array}$ & Nil & $\begin{array}{l}\text { Innovation } \\
\text { (simultaneous } \\
\text { reconstruction of } \\
\text { a contralateral } \\
\text { buccal mucosa } \\
\text { defect with SMF } \\
\text { has not been } \\
\text { reported) }\end{array}$ \\
\hline 3. & 47 & $\mathrm{M}$ & $\begin{array}{l}\text { Carcinoma left lower } \\
\text { alveolus involving } \\
\text { central arch }\end{array}$ & T4aN2M0 & $\begin{array}{l}\text { R- } 4 \mathrm{~cm} \\
\text { B-7 cm } \\
\text { CS- } 2.5 \mathrm{~cm}\end{array}$ & $\begin{array}{l}\text { Mucosa, } \\
\text { Skin over the } \\
\text { body of } \\
\text { mandible }\end{array}$ & $\begin{array}{l}\text { Mucosa } \\
(11 \times 7 \mathrm{~cm})\end{array}$ & $\begin{array}{l}\text { Skin over } \\
\text { body of } \\
\text { mandible } \\
(6 \times 4)\end{array}$ & $\begin{array}{l}\text { Left } \\
\text { FA, } \\
\text { CFV }\end{array}$ & $\begin{array}{l}\text { SMF } \\
\text { necrosis }\end{array}$ & $\begin{array}{l}\text { There were } \\
\text { recurrent } \\
\text { episodes of } \\
\text { arterial spasm } \\
\text { over } 5 \text { days. }\end{array}$ \\
\hline 4. & 50 & $\mathrm{~F}$ & $\begin{array}{l}\text { Adenoid cystic } \\
\text { carcinoma of right hard } \\
\text { palate }\end{array}$ & T4N0M0 & $\begin{array}{l}\text { Medial-4 } \\
\mathrm{cm} \\
\text { Lateral- } 4 \\
\mathrm{~cm}\end{array}$ & $\begin{array}{l}\text { Palate, } \\
\text { lateral nasal } \\
\text { wall }\end{array}$ & $\begin{array}{l}\text { Palate and to } \\
\text { provide bulk } \\
\text { over the } \\
\text { premaxillary } \\
\text { area (de- } \\
\text { epithelised } \\
\text { flap) } \\
(10 x 6 \mathrm{~cm})\end{array}$ & $\begin{array}{l}\text { Lateral nasal } \\
\text { wall }\end{array}$ & $\begin{array}{l}\text { Right } \\
\text { FA, } \\
\text { CFV }\end{array}$ & Nil & $\begin{array}{l}\text { Innovation (first report } \\
\text { of using SMF for } \\
\text { maxillary } \\
\text { reconstruction) }\end{array}$ \\
\hline 5. & 60 & $\mathrm{M}$ & $\begin{array}{l}\text { Carcinoma right lower } \\
\text { alveolus }\end{array}$ & T4aN1M0 & $\begin{array}{l}\mathrm{R}-3 \mathrm{~cm} \\
\mathrm{~B}-5 \mathrm{~cm}\end{array}$ & $\begin{array}{l}\text { Mucosa, } \\
\text { Cheek skin }\end{array}$ & $\begin{array}{l}\text { Mucosa, } \\
\text { Cheek skin } \\
(14 \times 7 \mathrm{~cm})\end{array}$ & NA & $\begin{array}{l}\text { Right } \\
\text { FA, } \\
\text { CFV }\end{array}$ & $\begin{array}{l}\text { SMF } \\
\text { couldn't be } \\
\text { harvested }\end{array}$ & $\begin{array}{l}\text { Accidentally, the } \\
\text { perforating } \\
\text { branch of the } \\
\text { peroral artery was } \\
\text { clipped before it } \\
\text { pierces the } \\
\text { interosseous } \\
\text { membrane }\end{array}$ \\
\hline 6. & 48 & M & $\begin{array}{l}\text { Carcinoma left lower } \\
\text { alveolus }\end{array}$ & T4a N1M0 & $\begin{array}{l}\mathrm{R}-3 \mathrm{~cm} \\
\text { B- } 7 \mathrm{~cm}\end{array}$ & $\begin{array}{l}\text { Mucosa, } \\
\text { Skin over the } \\
\text { body of } \\
\text { mandible }\end{array}$ & $\begin{array}{l}\text { Mucosa, } \\
\text { Skin over the } \\
\text { body of } \\
\text { mandible }(20 \times 7\end{array}$ & NA & $\begin{array}{l}\text { Left } \\
\text { FA, } \\
\text { CFV }\end{array}$ & $\begin{array}{l}\text { SMF harvest } \\
\text { was } \\
\text { abandoned } \\
\text { due }\end{array}$ & $\begin{array}{l}\text { SMF was supplied } \\
\text { predominantly by ATA } \\
\text { and minor branches } \\
\text { from perforating }\end{array}$ \\
\hline
\end{tabular}




\begin{tabular}{|c|c|c|c|c|c|c|c|c|c|c|c|}
\hline & & & & & & & $\mathrm{cm})$ & & & $\begin{array}{l}\text { unfamiliar } \\
\text { perforator } \\
\text { anatomy }\end{array}$ & branch. \\
\hline 7. & 25 & $\mathrm{M}$ & $\begin{array}{l}\text { Carcinoma left buccal } \\
\text { mucosa }\end{array}$ & T3N0M0 & $\begin{array}{l}\mathrm{R}-3 \mathrm{~cm} \\
\mathrm{~B}-7 \mathrm{~cm}\end{array}$ & $\begin{array}{l}\text { Mucosa, } \\
\text { Skin over the } \\
\text { body of } \\
\text { mandible }\end{array}$ & $\begin{array}{l}\text { Mucosa, } \\
\text { Skin over the } \\
\text { body of } \\
\text { mandible }(20 \times 7 \\
\mathrm{cm})\end{array}$ & NA & $\begin{array}{l}\text { Left } \\
\text { FA, } \\
\text { CFV }\end{array}$ & $\begin{array}{l}\text { SMF harvest } \\
\text { was } \\
\text { abandoned } \\
\text { due } \\
\text { unfamiliar } \\
\text { perforator } \\
\text { anatomy }\end{array}$ & $\begin{array}{l}\text { SMF was } \\
\text { supplied } \\
\text { predominantly by } \\
\text { ATA and minor } \\
\text { branches from } \\
\text { perforating } \\
\text { branch. }\end{array}$ \\
\hline 8. & 38 & $\mathrm{~F}$ & $\begin{array}{l}\text { Carcinoma right lower } \\
\text { alveolus }\end{array}$ & T4aN2bM0 & $\begin{array}{l}\mathrm{R}-3 \mathrm{~cm} \\
\mathrm{~B}-7 \mathrm{~cm}\end{array}$ & $\begin{array}{l}\text { Mucosa, } \\
\text { Cheek skin }\end{array}$ & $\begin{array}{l}\text { Mucosa } \\
(12 \times 7 \mathrm{~cm})\end{array}$ & $\begin{array}{l}\text { Cheek skin } \\
(7 \times 6 \mathrm{~cm})\end{array}$ & $\begin{array}{l}\text { Right } \\
\text { FA, } \\
\text { CFV }\end{array}$ & Nil & Nil \\
\hline 9. & 53 & $\mathrm{M}$ & $\begin{array}{l}\text { Carcinoma right gingivo- } \\
\text { buccal sulcus }\end{array}$ & yT4aN3bM0 & $\begin{array}{l}\mathrm{R}-3 \mathrm{~cm} \\
\mathrm{~B}-7 \mathrm{~cm} \\
\mathrm{~S}-2 \mathrm{~cm}\end{array}$ & $\begin{array}{l}\text { Mucosa, } \\
\text { Cheek skin } \\
\text { over the body } \\
\text { of mandible }\end{array}$ & $\begin{array}{l}\text { Mucosa } \\
(10 \times 7 \mathrm{~cm})\end{array}$ & $\begin{array}{l}\text { Cheek skin } \\
(7 \times 7 \mathrm{~cm})\end{array}$ & $\begin{array}{l}\text { Right } \\
\text { FA, } \\
\text { CFV }\end{array}$ & Nil & Nil \\
\hline 10. & 41 & M & $\begin{array}{l}\text { Carcinoma left lower } \\
\text { alveolus, leukoplakia } \\
\text { over the right buccal } \\
\text { mucosa and labial } \\
\text { mucosa }\end{array}$ & T4aN2bM0 & $\begin{array}{l}\mathrm{R}-3.5 \mathrm{~cm} \\
\mathrm{~B}-7 \mathrm{~cm}\end{array}$ & $\begin{array}{l}\text { Mucosa, } \\
\text { Cheek skin, } \\
\text { Contralateral } \\
\text { buccal mucosa, }\end{array}$ & $\begin{array}{l}\text { Mucosa, } \\
\text { Cheek skin } \\
(20 \times 8 \mathrm{~cm}) \\
\text { (double } \\
\text { islanded skin } \\
\text { flaps were } \\
\text { used) }\end{array}$ & $\begin{array}{l}\text { Contralateral } \\
\text { buccal } \\
\text { mucosa } \\
(7 \times 5 \mathrm{~cm})\end{array}$ & $\begin{array}{l}\text { Left } \\
\text { FA, } \\
\text { CFV }\end{array}$ & $\begin{array}{l}\text { SMF } \\
\text { necrosis }\end{array}$ & $\begin{array}{l}\text { SMF was necrosed due } \\
\text { to stretch \& } \\
\text { compression over the } \\
\text { mandible. }\end{array}$ \\
\hline 11. & 59 & $\mathrm{~F}$ & Carcinoma lower lip & T4aN2cM0 & $\begin{array}{l}\text { B-4 cm } \\
\text { CS- } 2.5 \mathrm{~cm}\end{array}$ & $\begin{array}{l}\text { Lower lip, floor } \\
\text { of mouth } \\
\text { Chin skin }\end{array}$ & $\begin{array}{l}\text { Floor of mouth } \\
\& \text { lip } \\
(14 \times 6 \mathrm{~cm})\end{array}$ & $\begin{array}{l}\text { Chin skin } \\
(7 \times 6 \mathrm{~cm})\end{array}$ & $\begin{array}{l}\text { Left } \\
\text { LA, } \\
\text { IJV }\end{array}$ & Nil & Nil \\
\hline 12. & 59 & $\mathrm{M}$ & $\begin{array}{l}\text { Carcinoma left buccal } \\
\text { mucosa }\end{array}$ & T4aN2bM0 & $\begin{array}{l}\mathrm{R}-4 \mathrm{~cm} \\
\mathrm{~B}-6 \mathrm{~cm}\end{array}$ & $\begin{array}{l}\text { Mucosa, } \\
\text { Palate, } \\
\text { ITF defect } \\
\text { Cheek skin }\end{array}$ & $\begin{array}{l}\text { Mucosa, } \\
\text { Palate, } \\
\text { To fill the } \\
\text { maxillary and } \\
\text { ITF dead space } \\
\text { (de-epithelized } \\
\text { portion) } \\
(20 \times 8 \mathrm{~cm})\end{array}$ & $\begin{array}{l}\text { Cheek skin } \\
(8 \times 7 \mathrm{~cm})\end{array}$ & $\begin{array}{l}\text { Left } \\
\text { FA, } \\
\text { CFV }\end{array}$ & Nil & $\begin{array}{l}\text { A large portion of the } \\
\text { fibula skin paddle was } \\
\text { de epithelized to } \\
\text { obliterate the dead } \\
\text { space as SMF was } \\
\text { available to close the } \\
\text { cheek defect. }\end{array}$ \\
\hline 13. & 50 & M & $\begin{array}{l}\text { Status post left segmental } \\
\text { mandibulectomy for } \\
\text { secondary mandible } \\
\text { reconstruction }\end{array}$ & NA & $\begin{array}{l}\mathrm{R}-3.5 \mathrm{~cm} \\
\mathrm{~B}-7 \mathrm{~cm} \\
\mathrm{CS}-2.5 \mathrm{~cm}\end{array}$ & $\begin{array}{l}\text { Mucosa. } \\
\text { Skin over } \\
\text { mandible and } \\
\text { chin }\end{array}$ & $\begin{array}{l}\text { Mucosa and } \\
\text { skin over cheek } \\
(20 \times 7 \mathrm{~cm}) \\
\text { (the skin } \\
\text { paddle flap was } \\
\text { islanded into } \\
\text { two flaps) }\end{array}$ & $\begin{array}{l}\text { Chin skin } \\
(7 \times 5 \mathrm{~cm})\end{array}$ & $\begin{array}{l}\text { Left, } \\
\text { STA } \\
\text { CFV }\end{array}$ & Nil & $\begin{array}{l}\text { Innovation (SMF was } \\
\text { used along with a } \\
\text { islanded double skin } \\
\text { paddle fibula flap) }\end{array}$ \\
\hline 14. & 52 & $\mathrm{M}$ & $\begin{array}{l}\text { Carcinoma left buccal } \\
\text { mucosa }\end{array}$ & cT4aNoMo & $\begin{array}{l}\mathrm{R}-4 \mathrm{~cm} \\
\mathrm{~B}-6 \mathrm{~cm}\end{array}$ & $\begin{array}{l}\text { Mucosa, } \\
\text { Palate, }\end{array}$ & $\begin{array}{l}\text { Mucosa, } \\
\text { Palate }\end{array}$ & $\begin{array}{l}\text { Cheek skin } \\
(4 \times 4 \mathrm{~cm})\end{array}$ & $\begin{array}{l}\text { Left } \\
\text { FA, }\end{array}$ & Nil & $\begin{array}{l}\text { Innovation (Soleus } \\
\text { muscle was included in }\end{array}$ \\
\hline
\end{tabular}




\begin{tabular}{|c|c|c|c|c|c|c|c|c|c|c|c|}
\hline & & & & & & $\begin{array}{l}\text { ITF defect, } \\
\text { Cheek skin }\end{array}$ & $(20 \times 10 \mathrm{~cm})$ & & $\mathrm{CFV}$ & & $\begin{array}{l}\text { the chimeric flap } \\
\text { design to obliterate the } \\
\text { maxilla and ITF defect) }\end{array}$ \\
\hline 15. & 59 & M & $\begin{array}{l}\text { Carcinoma left lower } \\
\text { alveolus }\end{array}$ & cT4aN0M0 & $\begin{array}{l}\mathrm{R}-3 \mathrm{~cm} \\
\mathrm{~B}-7 \mathrm{~cm}\end{array}$ & $\begin{array}{l}\text { Mucosa, } \\
\text { Skin over the } \\
\text { body of } \\
\text { mandible }\end{array}$ & $\begin{array}{l}\text { Mucosa } \\
(12 \times 7 \mathrm{~cm} 0\end{array}$ & $\begin{array}{l}\text { Skin over } \\
\text { the mandible } \\
(5 \times 4 \mathrm{~cm})\end{array}$ & $\begin{array}{l}\text { Left } \\
\text { FA, } \\
\text { CFV }\end{array}$ & Nil & Nil \\
\hline
\end{tabular}

(B- body; R- ramus; CS- central segment; SMF- supramalleolar flap; FA- facial artery, LA- lingual artery; STA- superior thyroid artery; CFV- common facial vein; IJVinternal jugular vein; ATA- anterior tibial artery; NA- not applicable) 


\section{Case 2 (Composite mandible defect of the central segment):}

A 59-year-old female patient was diagnosed to have a carcinoma lower lip (cT4aN2cM0). She underwent WLE of the lower lip, composite central arch segmental mandibulectomy, and neck dissection. A CFSMF was harvested from the left leg. Fibula (central segment-4cm; body $-2.5 \mathrm{~cm})$ along with skin paddle $(7 x 6 \mathrm{~cm})$ was used to reconstruct the mandible and the mucosal defect. A portion of the fibula skin paddle was de-epithelised and was used to cover the plate at the osteotomy site. SMF (7x6cm) was used to reconstruct the skin over the chin. The recipient vessels were the right lingual artery and common facial vein. The patient underwent debridement of partial necrosis of the vermillion on a postoperative day 5. The patient has an uneventful recovery thereafter (Figure 4).
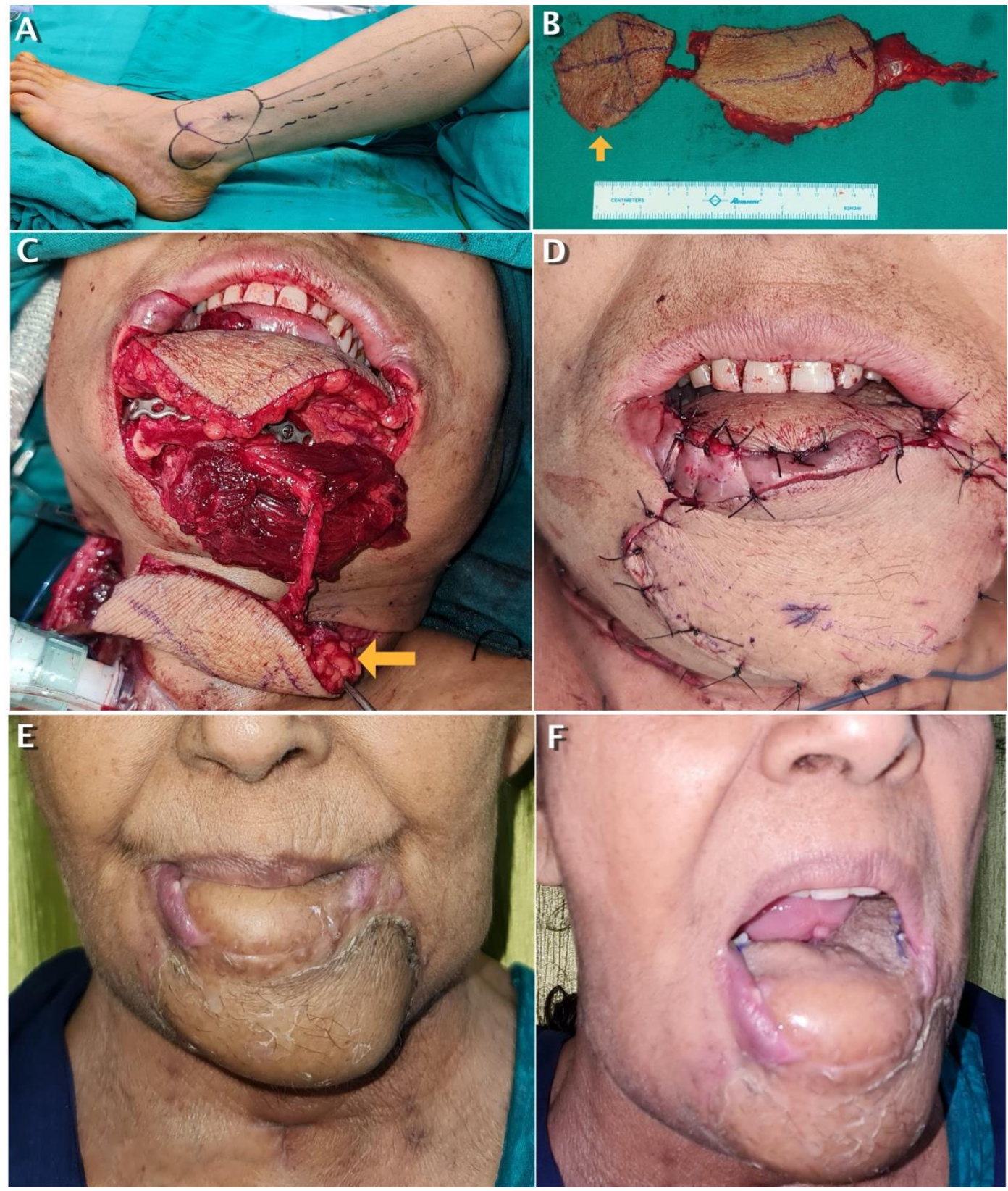
Figure 4: Image showing (A) marking of CFSMF, (B) harvested CFSMF (yellow arrow indicates SMF), (C) following inset of fibula flap (yellow arrow indicated SMF before inset), (D) inset of fibula flap and the chin skin was covered by SMF, (E, F) well-settled flaps.

\section{Case 3 (Segmental mandible reconstruction with resurfacing of contralateral buccal mucosa defect):}

A 38-year-old male patient was diagnosed with carcinoma right buccal mucosa (cT4aN1M0) and oral submucous fibrosis (OSMF). He underwent WLE of right buccal mucosa, segmental mandibulectomy, upper alveolectomy and selective neck dissection. He also underwent release of the left buccal mucosa OSMF. CFSMF was harvested from the right leg. Fibula (ramus-3cm; body-6.5cm) along with the skin paddle $(14 \times 8 \mathrm{~cm})$ was used to reconstruct the segmental mandibulectomy defect. The SMF flap (7x6cm) was used to cover the defect in the left buccal mucosa. The pedicle of the SMF was tunneled across the floor of the mouth. The recipient vessels were the right facial artery and common facial vein. The postoperative stay was uneventful (Figure 5,6).

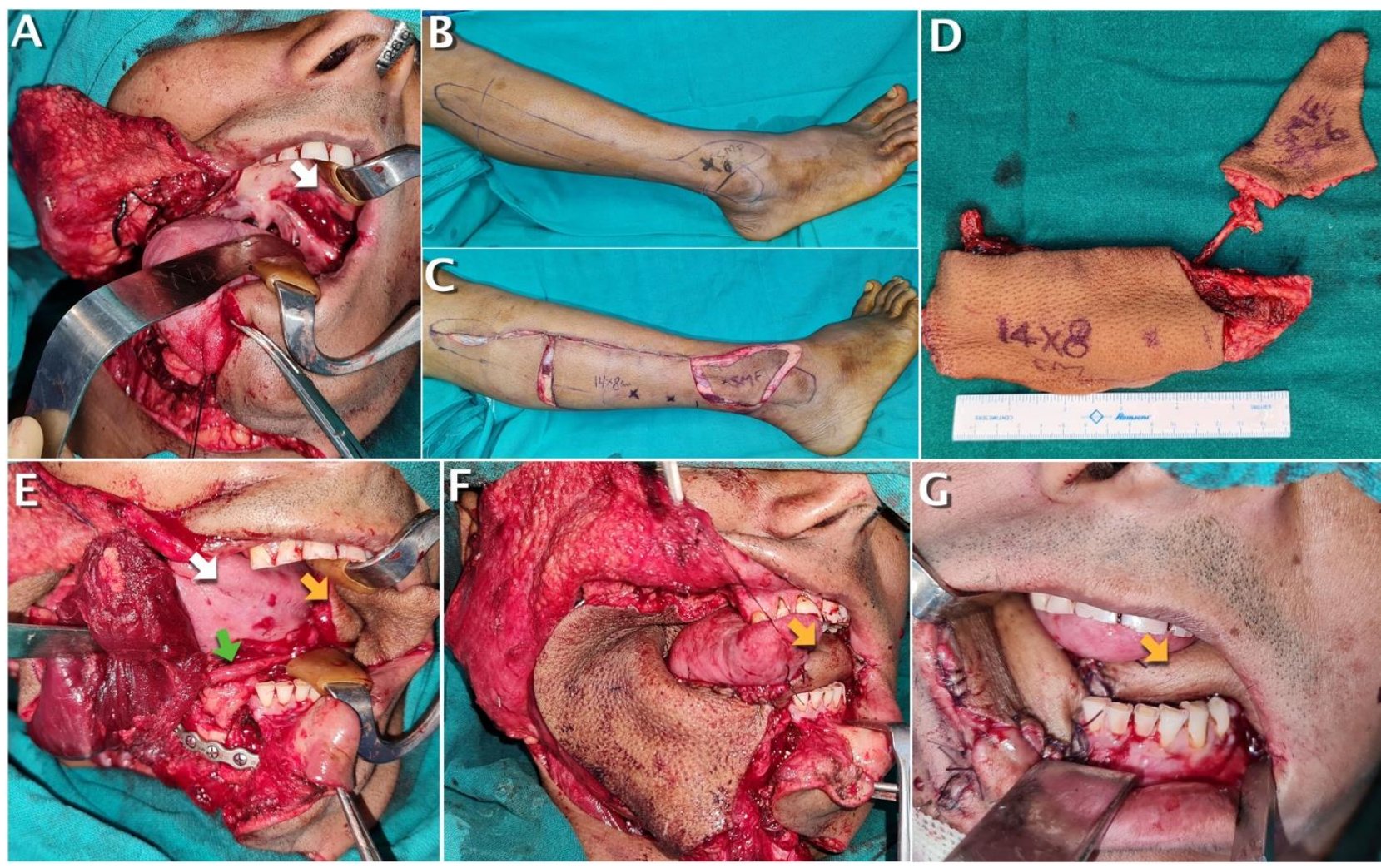

Figure 5: Image showing (A) segmental mandibulectomy defect on the right side and buccal mucosa defect (white arrow) on the left side, (B-D) marking \& harvest of CFSMF, (E) following bone inset the SMF was transposed to the buccal mucosa on the left side, mucosa in the floor of the mouth was split to accommodate the pedicle (green arrow) of the SMF (yellow arrow), white arrow indicated the tongue. (F, G) inset of SMF (yellow arrow) and fibula skin paddle. 


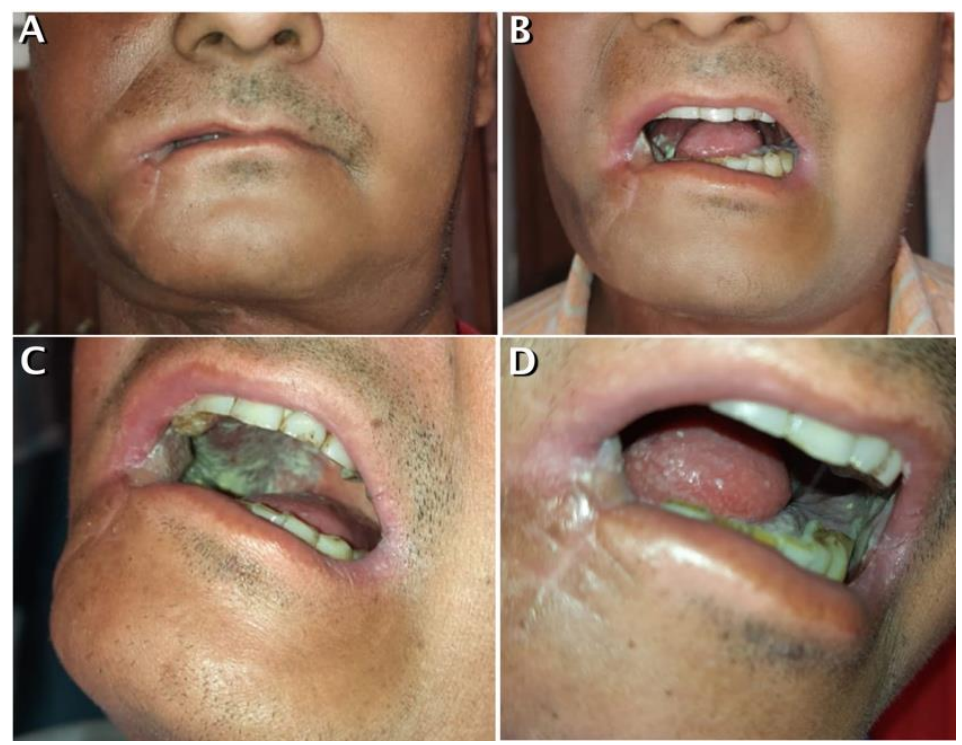

Figure 6: Image showing (A, B) post-op appearance, (C, D) fibula skin paddle and SMF respectively.

\section{Case 4 (Total maxillectomy defect with creation of lateral nasal wall):}

A 50-year-old female patient was diagnosed with adenoid cystic carcinoma of the right hard palate. She underwent total maxillectomy with resection of the floor of the orbit and neck dissection. A CFSMF was harvested from the right leg. Fibula (medial segment $-4 \mathrm{~cm}$, lateral segment $4 \mathrm{~cm}$ ) along with the skin paddle $(9 \times 7 \mathrm{~cm})$ with a single perforator was used to reconstruct the maxilla and the palatal defect. Following flap inset, over the palate, the skin paddle was de epithelized to provide bulk over the zygoma region and to cover the orbital plate margin. SMF was used to reconstruct the lateral nasal wall. The floor of the orbit was reconstructed with a titanium orbital plate. The recipient vessels were right facial artery and common facial vein._The patient had an uneventful postoperative stay (Figure 7).

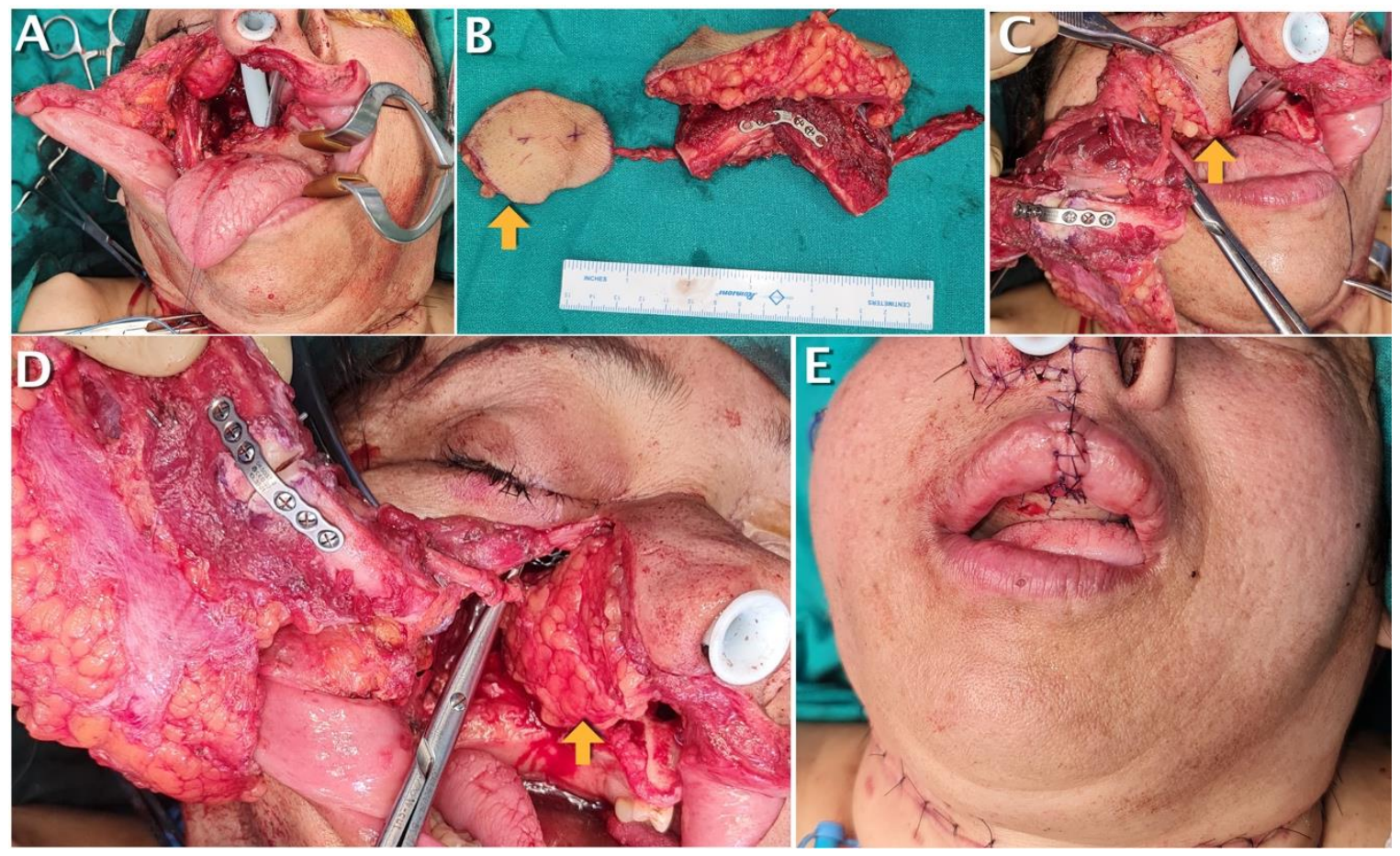

Figure 7: Image showing (A) right total maxillectomy defect, (B) harvested CFSMF, (C) partial inset of SMF to cover the lateral nasal wall defect, (D) completion of SMF inset before fibula flap inset, (E) palatal defect covered with fibula skin paddle. 


\section{DISCUSSION:}

We proposed four innovative applications CFSMF in our series. Utilization of CFSMF for simultaneous reconstruction of the mandibular defect and a contralateral buccal mucosal defect was never described before. Two new chimeric flap combinations were proposed, one with inclusion of soleus in the flap, the other inclusion of islanded double paddle fibula skin paddle (Table 1). The fourth one is the application of CFSMF for total maxillary reconstruction. To the best of our knowledge, these entities weren't described before. The flap combination provides an independent supramalleolar skin paddle in addition to the osteo-myocutaneous fibula flap with a single set of anastomoses. The pedicle length of the SMF provides freedom to reconstruct the three-dimensional defects (Video 3).

We prefer to use a double skin paddle fibula flap ${ }^{8,9}$ for the above-mentioned defects. However, there might not be suitable perforator anatomy always. The freedom of flap inset is also restricted in a double paddle fibula flap when compared to the CFSMF. On other occasions, a fibula skin paddle might be insufficient to provide a comfortable three-dimensional flap inset. ${ }^{10}$ In such scenarios we found CFSMF has an important role. Potter JK et al ${ }^{11}$ demonstrated a distinct advantage of proximal peroneal perforator when using a dual skin fibula flap. In our experience, we often noticed that the proximal peroneal perforators have variable anatomy and on several occasions they are absent. The perforator anatomy of SMF is predictable. ${ }^{12}$ An innovative two in one double free flap from single fibula osteocutaneous unit was proposed for similar indications. ${ }^{13}$ The disadvantage of this technique is the requirement of two sets of anastomoses.

In two patients, the perforating branch of peroneal artery had a large communicating branch to the anterior tibial vessels. In this scenario, we were unsure if we could harvest the SMF based on the peroneal artery. In addition to this, there were multiple small perforators from the perforating branch of peroneal artery. Hence, we abandoned the SMF harvest. As we gained experience, we could successfully harvest flap even in these anatomical patterns. We don't recommend a CT angiography to rule out these anatomical variations as SMF could be reliably harvested in spite of the variations. None of the authors had seen this procedure beforehand. We recommend practicing the surgery on a cadaver if feasible. The skin perforator of SMF arising from the perforating branch of peroneal artery may be single or it may be replaced by multiple small branches. Arterial spasm was seen in all SMF flaps. Liberal use of papaverine, warm saline, and normalizing the systolic blood pressure were all necessary to relieve the spasm. The perforating branch of the peroneal artery has multiple branches along its course, meticulous clipping of these branches is necessary to avoid hemorrhagic complications. The technique needs greater perforator dissection skill when compared to harvest a free fibula flap. On average extra 60 to 90 minutes were required to harvest SMF.

When compared to double free flap or chimeric scapula flaps, CFSMF has several advantages and disadvantages (Table 2). While harvesting a fibula flap, a suitable soleus muscle perforator may not be always available to obliterate the dead space, especially in the maxillary or ITF regions. Rarely, a very large surface area of cervicofacial skin needs to be reconstructed along with the mandible. In both of the above scenarios, a double-free flap, chimeric scapula flap, or an iliac flap have a very distinct advantage over the CFSMF. The limitations of SMF are its thinness \& the smaller flap surface area. A Larger SMF harvest leads to a defect over the anterior aspect of the ankle joint or dorsum of the foot; a skin graft could lead to stiffness or restriction of ankle joint mobility. However, either a single chimeric free flap or double free flaps should be appropriately used as a part reconstructive surgeon's armamentarium. ${ }^{14}$ The limitations of our study were limited sample size, lesser follow-up duration, and a retrospective study design.

\section{Table 2. Comparison of CFSMF with double free flap and chimeric scapula flaps}

\begin{tabular}{|l|l|}
\hline Advantages & Disadvantages \\
\hline Two flaps with a single set of anastomoses & Challenging perforator dissection (SMF) \\
\hline Feasibility of two team approach & $\begin{array}{l}\text { Limited flap volume (in the absence of a suitable } \\
\text { soleus perforator) }\end{array}$ \\
\hline Thin pliable flap (SMF) & Lesser flap surface area (SMF) \\
\hline Lesser operative time & Prone to arterial spasm (SMF) \\
\hline Position change is not necessary & $\begin{array}{l}\text { Extra care is required to protect the SMF pedicle } \\
\text { during fibula flap harvest }\end{array}$ \\
\hline Needs lesser resources \& man power & Unfamiliar anatomy \\
\hline Single donor site & Variation in skin perforator patterns (SMF) \\
\hline
\end{tabular}

SMF: Supramalleolar flap 


\section{CONCLUSION:}

The utilization of CFSMF in day-to-day practice is feasible with certain modifications. These modifications include a prior practice on cadaver if feasible, appropriate management of arterial spasm. It a good choice for the reconstruction of selected composite mandibular \& maxillary defects. The flap combination has several innovative applications as described and a study with a larger sample size would show wider perspectives on this chimeric flap.

\section{REFERENCES:}

1. Balasubramanian D, Thankappan K, Kuriakose MA, et al. Reconstructive indications of simultaneous double free flaps in the head and neck: a case series and literature review. Microsurgery. 2012 Sep;32(6):423-30.

2. Jeng SF, Kuo YR, Wei FC, et al. Reconstruction of extensive composite mandibular defects with large lip involvement by using double free flaps and fascia lata grafts for oral sphincters. Plast Reconstr Surg. 2005 Jun;115(7):1830-6.

3. Wei FC, Celik N, Chen HC, et al. Combined anterolateral thigh flap and vascularized fibula osteoseptocutaneous flap in reconstruction of extensive composite mandibular defects. Plast Reconstr Surg. 2002 Jan;109(1):45-52.

4. Hasan Z, Gore SM, Ch'ng S, et al. Options for configuring the scapular free flap in maxillary, mandibular, and calvarial reconstruction. Plast Reconstr Surg. 2013 Sep;132(3):645-655.

5. Chen HC, Demirkan F, Wei FC, et al. Free fibula osteoseptocutaneous-pedicled pectoralis major myocutaneous flap combination in reconstruction of extensive composite mandibular defects. Plast Reconstr Surg. 1999 Mar;103(3):839-45.

6. Sicilia-Castro D, Garcia-Perla A, Infante-Cossio P, et al. Combined fibula osteoseptocutaneous-lateral supramalleolar flap for reconstruction of composite mandibular defects. Plast Reconstr Surg. 2003;111:2003-2008.

7. Massarelli O, Gobbi R, Biglio A, et al. Chimeric lateral supramalleolar artery perforator fibula free flap in the reconstruction of composite head and neck defects. Plast Reconstr Surg. 2014 Jan;133(1):130-136.

8. Burgueño García M, Cebrián Carretero JL, del Castillo Pardo de Vera JL, et al. Colgajo libre de peroné con doble isla cutánea para la reconstrucción orofacial. Presentación de un caso [Double skin paddle fibula free flap in orofacial reconstruction. Case report]. An Otorrinolaringol Ibero Am. 2005;32(1):77-85.

9. Yadav PS, Ahmad QG, Shankhdhar VK, Nambi G I. Reconstruction of oncological oro-mandibular defects with double skin paddled-free fibula flap: A prudent alternative to double flaps in resource-constrained centres. J Can Res Ther 2012;8:91-5.

10. Cheng MH, Saint-Cyr M, Ali RS, Chang KP, Hao SP, Wei FC. Osteomyocutaneous peroneal artery-based combined flap for reconstruction of composite and en bloc mandibular defects. Head Neck. 2009 Mar;31(3):361-70.

11. Potter JK, Lee MR, Oxford L, Wong C, Saint-Cyr M. Proximal peroneal perforator in dual-skin paddle configuration of fibula free flap for composite oral reconstruction. Plast Reconstr Surg. 2014 Jun;133(6):1485-1492.

12. Masquelet AC, Beveridge J, Romana C, Gerber C. The lateral supramalleolar flap. Plast Reconstr Surg. 1988;81(1):74-81.

13. Yadav PS, Shankhdhar VK, Dushyant J, et al. Two in one: Double free flap from a single free fibula osteocutaneous unit. Indian J Plast Surg. 2012 Sep;45(3):459-65.

14. Raghuram AC, Manfro G, Teixeira GV, et al. Use of Single Chimeric Free Flaps or Double Free Flaps for Complex Head and Neck Reconstruction. J Reconstr Microsurg. 2021 Apr 14. doi: 10.1055/s-0041-1727188.

\section{AUTHORS}

First Author - Ravikiran Naalla, M.Ch. Consultant, Division of Reconstructive Microsurgery, Department of Surgical Oncology, Rajiv Gandhi Cancer Institute \& Research Center, New Delhi. Email: ravi_2488@yahoo.co.in

Second Author - Rajan Arora, M.Ch. Senior Consultant, Division of Reconstructive Microsurger. Department of Surgical Oncology, Rajiv Gandhi Cancer Institute \& Research Center, New Delhi. Email: rajan_ritu@rediffmail.com

Third Author - Kripa Shanker Mishra, M.Ch. Consultant, Division of Reconstructive Microsurgery, Department of Surgical Oncology, Rajiv Gandhi Cancer Institute \& Research Center, New Delhi. Email: drksmishra25@gmail.com

Fourth Author- Ajay Kumar Dewan, M. Ch. Director, Surgical Oncology, Department of Surgical Oncology,Rajiv Gandhi Cancer Institute \& Research Centre, Rohini, New Delhi. Email: dewan.ajay@gmail.com

Fifth Author- Mudit Agarwal, Senior Consultant, Surgical Oncology, Department of Surgical Oncology,Rajiv Gandhi Cancer Institute \& Research Centre, Rohini, New Delhi. Email: mudit1000@yahoo.com

Sixth Author- Saket Srivastava, Fellow, Reconstructive Microsurgery Unit, Department of Surgical Oncology, Rajiv Gandhi Cancer Institute \& Research Centre, Rohini, New Delhi. Email: saket.kgmu@gmail.com 
Seventh Author- Aditya Narayan Choudhary, Attending Consultant, Reconstructive Microsurgery Unit, Department of Surgical Oncology, Rajiv Gandhi Cancer Institute \& Research Centre, Rohini, New Delhi. Email: choudharyadityanarayan@gmail.com

Correspon Correspondence Author - Ravikiran Naalla, M.Ch. Consultant, Division of Reconstructive Microsurgery, Department of Surgical Oncology, Rajiv Gandhi Cancer Institute \& Research Center, New Delhi. Email: ravi_2488@yahoo.co.in , Mobile- +91 9821826580 